\title{
The carbon budget of South Asia
}

\author{
P. K. Patra ${ }^{1}$, J. G. Canadell ${ }^{2}$, R. A. Houghton ${ }^{3}$, S. L. Piao $^{4}$, N.-H. Oh ${ }^{5}$, P. Ciais $^{6}$, K. R. Manjunath ${ }^{7}$, A. Chhabra ${ }^{7}$,

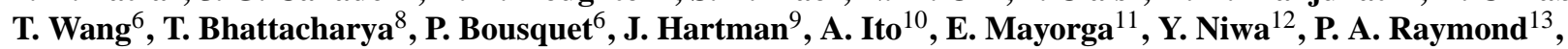 \\ V. V. S. S. Sarma ${ }^{14}$, and R. Lasco ${ }^{15}$ \\ ${ }^{1}$ Research Institute for Global Change, JAMSTEC, Yokohama 236 0001, Japan \\ ${ }^{2}$ Global Carbon Project, CSIRO Marine and Atmospheric Research, Canberra, ACT 2601, Australia \\ ${ }^{3}$ Woods Hole Research Center, 149 Woods Hole Road, Falmouth, MA 02540, USA \\ ${ }^{4}$ Peeking University, Beijing 100871, China \\ ${ }^{5}$ Seoul National University, 1 Gwanak-ro, Gwanak-gu, Seoul, South Korea \\ ${ }^{6}$ IPSL - LSCE, CEA CNRS UVSQ, Centre d'Etudes Orme des Merisiers, 91191 Gif sur Yvette, France \\ ${ }^{7}$ Space Application Centre, ISRO, Ahmedabad 380 015, India \\ ${ }^{8}$ National Bureau of Soil Survey and Land use Planning (ICAR) Amravati Road, Nagpur 440 033, India \\ ${ }^{9}$ Institute for Biogeochemistry and Marine Chemistry, 20146, Hamburg, Germany \\ ${ }^{10}$ National Institute for Environmental Studies, Tsukuba, Ibaraki 305-8506, Japan \\ ${ }^{11}$ Applied Physics Laboratory, University of Washington, Seattle, WA 98105, USA \\ ${ }^{12}$ Meteorological Research Institute, Tsukuba, Japan \\ ${ }^{13}$ Yale University, New Haven, CT 06511, USA \\ ${ }^{14}$ National Institute of Oceanography, Visakhapatnam 530 017, India \\ ${ }^{15}$ The World Agroforestry Centre (ICARF), Laguna 4031, Philippines
}

Correspondence to: P. K. Patra (prabir@jamstec.go.jp)

Received: 27 August 2012 - Published in Biogeosciences Discuss.: 5 October 2012

Revised: 22 December 2012 - Accepted: 2 January 2013 - Published: 25 January 2013

\begin{abstract}
The source and sinks of carbon dioxide $\left(\mathrm{CO}_{2}\right)$ and methane $\left(\mathrm{CH}_{4}\right)$ due to anthropogenic and natural biospheric activities were estimated for the South Asian region (Bangladesh, Bhutan, India, Nepal, Pakistan and Sri Lanka). Flux estimates were based on top-down methods that use inversions of atmospheric data, and bottom-up methods that use field observations, satellite data, and terrestrial ecosystem models. Based on atmospheric $\mathrm{CO}_{2}$ inversions, the net biospheric $\mathrm{CO}_{2}$ flux in South Asia (equivalent to the Net Biome Productivity, NBP) was a sink, estimated at $-104 \pm 150 \mathrm{TgC}^{-1}$ during 2007-2008. Based on the bottom-up approach, the net biospheric $\mathrm{CO}_{2}$ flux is estimated to be $-191 \pm 193 \mathrm{TgCyr}^{-1}$ during the period of 2000-2009. This last net flux results from the following flux components: (1) the Net Ecosystem Productivity, NEP (net primary production minus heterotrophic respiration) of $-220 \pm 186 \mathrm{TgC} \mathrm{yr}^{-1}$ (2) the annual net carbon flux from land-use change of $-14 \pm 50 \mathrm{TgC}^{-1}$, which resulted from a sink of $-16 \mathrm{TgCyr}^{-1}$ due to the establishment of tree plantations and wood harvest, and a source of $2 \mathrm{TgC}^{-1}$ due to the expansion of croplands; (3) the river-
\end{abstract}

ine export flux from terrestrial ecosystems to the coastal oceans of $+42.9 \mathrm{TgCyr}^{-1}$; and (4) the net $\mathrm{CO}_{2}$ emission due to biomass burning of $+44.1 \pm 13.7 \mathrm{TgC}^{-1}$. Including the emissions from the combustion of fossil fuels of $444 \mathrm{TgCyr}^{-1}$ for the 2000 s, we estimate a net $\mathrm{CO}_{2}$ landatmosphere flux of $297 \mathrm{TgC} \mathrm{Cyr}^{-1}$. In addition to $\mathrm{CO}_{2}$, a fraction of the sequestered carbon in terrestrial ecosystems is released to the atmosphere as $\mathrm{CH}_{4}$. Based on bottom-up and top-down estimates, and chemistry-transport modeling, we estimate that $37 \pm 3.7 \mathrm{TgC}-\mathrm{CH}_{4} \mathrm{yr}^{-1}$ were released to atmosphere from South Asia during the 2000s. Taking all $\mathrm{CO}_{2}$ and $\mathrm{CH}_{4}$ fluxes together, our best estimate of the net land-atmosphere $\mathrm{CO}_{2}$-equivalent flux is a net source of $334 \mathrm{TgCyr}^{-1}$ for the South Asian region during the 2000s. If $\mathrm{CH}_{4}$ emissions are weighted by radiative forcing of molecular $\mathrm{CH}_{4}$, the total $\mathrm{CO}_{2}$-equivalent flux increases to $1148 \mathrm{TgC} \mathrm{yr}^{-1}$ suggesting there is great potential of reducing $\mathrm{CH}_{4}$ emissions for stabilizing greenhouse gases concentrations. 


\section{Introduction}

South Asia (Bangladesh, Bhutan, India, Nepal, Pakistan and Sri Lanka) is home to 1.6 billion people and covers an area of $4.5 \times 10^{6} \mathrm{~km}^{2}$. These countries are largely self-sufficient in food production through a wide range of natural resources, and agricultural and farming practices (FRA, 2010). However, due to rapid economic growth, fossil fuel emissions have increased from $213 \mathrm{TgC} \mathrm{yr}^{-1}$ in 1990 to about $573 \mathrm{TgC}^{-1}$ in 2009 (Boden et al., 2011). A detailed budget of $\mathrm{CO}_{2}$ exchange between the earth's surface and the atmosphere is not available for the South Asian region due to a sparse network of key carbon observations such as atmospheric $\mathrm{CO}_{2}$, soil carbon stocks, woody biomass, and $\mathrm{CO}_{2}$ uptake and release by managed and unmanaged ecosystems. Only recently, Patra et al. (2011a) estimated net $\mathrm{CO}_{2}$ fluxes at seasonal time intervals by inverse modeling (also known as top-down approach), revealing strong carbon uptake of $149 \mathrm{Tg} \mathrm{C}$ month $^{-1}$ during July-September following the summer monsoon rainfall.

The region is also very likely to be a strong source of $\mathrm{CH}_{4}$ due to rice cultivation by an amount that still remains controversial in the literature (Cicerone and Shetter, 1981; Fung et al., 1991; Yan et al., 2009; Manjunath et al., 2011), and large numbers of ruminants linked to religious and farming practices (Yamaji et al., 2003; Chhabra et al., 2009a). Since the green revolution there has been an increase in $\mathrm{CH}_{4}$ emissions owing to the introduction of high-yielding crop species, increased use of nitrogen and phosphorus fertilizers, and expansion of cropland areas to meet the food demands of a growing human population in countries of South Asia (Bouwman et al., 2002; Patra et al., 2012a).

South Asia has also undergone significant changes in the rates of land- use change over the last $20 \mathrm{yr}$ contributing to the net carbon exchange. India alone has increased the extent of forest plantations by $4.5 \mathrm{Mha}$ ( $\sim 7 \%$ of 64 Mha in 2010) from 1990 to 2010 leading to a $26 \%$ increase in the carbon stock in living forest biomass (FRA, 2010).

In this paper we establish for the first time the net carbon budget of South Asia, including $\mathrm{CO}_{2}$ and $\mathrm{CH}_{4}$, and its interannual variability for the period 1990-2009. We achieve this goal by synthesizing the results of multiple approaches that include (1) atmospheric inversions as so-called top-down methods, and (2) fossil fuel consumption, forest/soil inventories, riverine exports, remote sensing products and dynamic global vegetation models as bottom-up methods. The comparison of independent and partially independent estimates from these various methods help to define the uncertainty in our knowledge on the South Asian carbon budget. Finally, we attempt to separate the net carbon balance into its main contributing fluxes including fluxes from net primary production, heterotrophic respiration, land-use change, fire, and riverine export to coastal oceans. This effort is consistent with and a contribution to the REgional Carbon Cycle As-

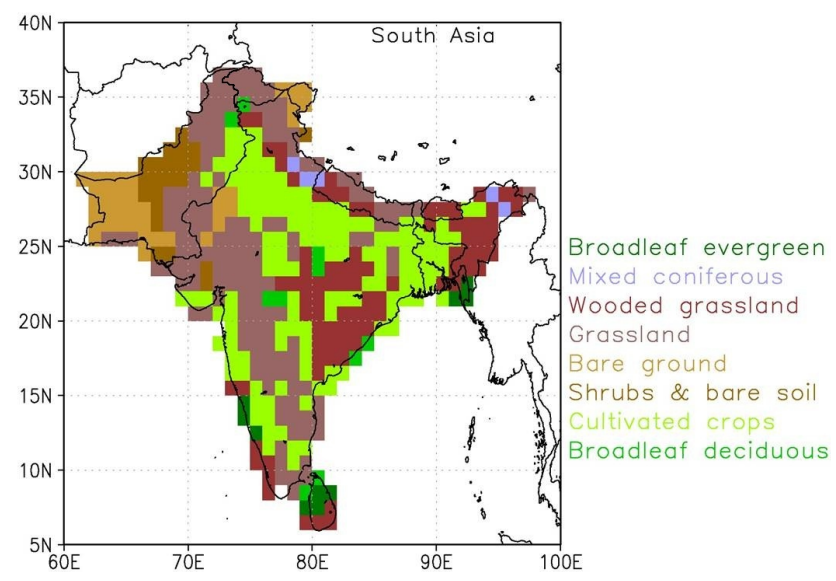

Fig. 1. Landmass selected for the RECCAP South Asia region following the definition of the United Nations and by accounting for the similarities in vegetation types as shown by the colored map at $1 \times 1^{\circ}$ spatial resolution (DeFries and Townshend, 1994).

sessment and Processes (Canadell et al., 2011; Patra et al., 2012b).

\section{Materials and methods}

The South Asian region designated for this study is shown in Fig. 1, along with the basic ecosystem types (DeFries and Townshend, 1994). A large fraction of the area is cultivated croplands and grassland or wooded grassland $\left(1.3 \times 10^{6} \mathrm{~km}^{2}\right.$ and $1.5 \times 10^{6} \mathrm{~km}^{2}$ or $0.89 \times 10^{6} \mathrm{~km}^{2}$, respectively). The rest of the area is classified as bare soil, shrubs, broadleaf evergreen, broadleaf deciduous and mixed coniferous $\left(0.35 \times 10^{6} \mathrm{~km}^{2}, 0.22 \times 10^{6} \mathrm{~km}^{2}\right.$, $0.11 \times 10^{6} \mathrm{~km}^{2}, 0.10 \times 10^{6} \mathrm{~km}^{2}$ and $0.05 \times 10^{6} \mathrm{~km}^{2}$, respectively). The region is bounded by the Indian Ocean in the south and the Himalayan mountain range in the north. The meteorological conditions over the South Asian region are controlled primarily by the movement of the inter-tropical convergence zone (ITCZ). When the ITCZ is located over the Indian Ocean (between Equator to $5^{\circ} \mathrm{S}$ ) during boreal autumn, winter and spring, the region is generally dry without much occurrence of rainfall. When the ITCZ is located north of the region, about $70 \%$ of precipitations occur during the boreal summer (June-September). Some of these prevailing meteorological conditions are discussed in relations to $\mathrm{CO}_{2}$ and $\mathrm{CH}_{4}$ surface fluxes, and concentration variations in earlier studies (Patra et al., 2009, 2011a).

\subsection{Emissions from the combustion of fossil fuels and cement production}

Carbon dioxide emission statistics were taken from the CDIAC database of consumption of fossil fuels and cement production (Boden et al., 2011). $\mathrm{CO}_{2}$ emissions were 
derived from energy statistics published by the United Nations (2010) and processed according to methods described in Marland and Rotty (1984). $\mathrm{CO}_{2}$ emissions from the production of cement were based on data from the US Department of Interior's Geological Survey (USGS, 2010), and emissions from gas flaring were derived from data provided by the UN, US Department of Energy's Energy Information Administration (1994), and Rotty (1974).

\subsection{Emissions from land use and land-use change}

Emissions from land-use change include the net flux of carbon between the terrestrial biosphere and the atmosphere resulting from deliberate changes in land cover and land use (Houghton, 2003). Flux estimates are based on a book keeping model that tracks living and dead carbon stocks including wood products for each hectare of land cultivated, harvested or reforested. Data on land-use change was from the Global Forest Resource Assessment of the Food and Agriculture Organization (FRA, 2010; http://www.fao.org/forestry/fra/fra2010/en; accessed 15 December 2012). We also extracted information from national communication reports to the United Nations Framework Convention on Climate Change (http://unfccc.int/national_reports/items/1408.php; accessed 15 December 2012).

\subsection{Fire emissions}

Fire emissions for the region were obtained from the Global Fire Emissions Database version 3.1 (GFEDv3.1). GFED is based on a combination of satellite information on fire activity and vegetation productivity (van der Werf et al., 2006, 2010). The former is based on burned area, active fires, and fAPAR from various satellite sensors, and the latter is estimated with the satellite-driven Carnegie Ames Stanford Approach (CASA) model.

\subsection{Transport of riverine carbon}

To estimate the land to ocean carbon flux, we used the six ocean coastline segments with their corresponding river catchments for South Asia, as described by the COSCAT database (Meybeck et al., 2006). The lateral transport of carbon to the coast was estimated at the river basin scale using the Global Nutrient Export from WaterSheds (NEWS) model framework (Mayorga et al., 2010), including NEWS basin areas. The carbon species models are hybrid empirically and conceptually based models that include single and multiple linear regressions developed by the NEWS effort and Hartmann et al. (2009), and single-regression relationships assembled from the literature. Modeled dissolved and particulate organic carbon (DOC and POC) loads used here (from Mayorga et al., 2010) were generated largely using drivers corresponding to the year 2000, including observed hydroclimatological forcings, though some parameters and the ob- served loads are based on data spanning the previous two decades. Total suspended sediment (TSS) exports were also estimated by NEWS. Dissolved inorganic carbon (DIC) estimates correspond to weathering-derived bicarbonate exports and do not include $\mathrm{CO}_{2}$ supersaturation; the statistical relationships developed by Hartmann et al. (2009) were adjusted in highly weathered tropical soils (ferralsols) to $25 \%$ of the modeled values found in Hartmann et al. (2009) to account for overestimates relative to observed river exports (J. Hartmann and N. Moosdorf, unpublished data); adjusted gridcell scale exports were aggregated to the basin scale using NEWS basin definitions (Mayorga et al., 2010), then reduced by applying a NEWS-based, basin-scale consumptive water removal factor from irrigation withdrawals (Mayorga et al., 2010). DIC modeled estimates represent approximately the years 1970-2000. Overall, carbon loads may be characterized as representing general conditions for the period 1980 2000. Carbon, sediment and water exports were aggregated from the river basin scale to corresponding COSCAT regions.

\subsection{Fluxes by terrestrial ecosystem models}

We use the net primary productivity (NPP) and heterotrophic respiration (RH) simulated by ten ecosystem models: HyLand, Lund-Potsdam-Jena DGVM (LPJ), ORCHIDEE, Sheffield-DGVM, TRIFFID, LPJ_GUESS, NCAR_CLM4C, NCAR_CLM4CN, OCN and VEGAS. The models used the protocol as described by the carbon cycle model intercomparison project (TRENDY) (Sitch et al., 2012; Piao et al., 2012; http://dgvm.ceh.ac.uk/system/files/Trendy_protocol\% 20_Nov2011_0.pdf), where each model was run from its pre-industrial equilibrium (assumed at the beginning of the 1900 s) to 2009 . We present net ecosystem productivity $(\mathrm{NEP}=\mathrm{NPP}-\mathrm{RH})$ from two simulation cases; S1: where models consider change in atmospheric $\mathrm{CO}_{2}$ concentration alone, and $\mathrm{S} 2$ : where models consider change in climate and rising atmospheric $\mathrm{CO}_{2}$ concentration.

The historical changes in atmospheric $\mathrm{CO}_{2}$ concentration for the period of 1901-2009 were derived from ice core records and atmospheric observations from the Scripps Institution of Oceanography (Keeling et al., 2001). For the climate forcing datasets, monthly climate data for the period of 1901-2009 from CRUNCEP datasets with a spatial resolution $0.5^{\circ} \times 0.5^{\circ}$ (http://dods.extra.cea.fr/data/p529viov/cruncep/) were used. Information on land-use change was derived from HYDE 3.1 land cover dataset (Goldewijk, 2001, ftp.pbl.nl; path: /hyde/hyde31_final). These models do not include lateral fluxes of $\mathrm{C}$ exported away from ecosystems (from soils to rivers, biomass harvested products) nor fluxes resulting from forest and agricultural management.

We performed correlation analyses between detrended net carbon flux and two climate drivers, annual temperature and annual precipitation, in order to diagnose the modeled interannual response of net carbon fluxes to these drivers (positive 
for carbon source, negative for carbon sink). The detrended fluxes were calculated by removing the 30-yr linear trend of each variable (net carbon flux, annual temperature and annual precipitation), in order to avoid the confounding effects of the simultaneous trends of temperature or rainfall, with those of other environmental drivers such as rising $\mathrm{CO}_{2}$.

\subsection{Atmospheric inverse models}

The biospheric (non-fossil $\quad \mathrm{CO}_{2}$ ) $\mathrm{CO}_{2}$ fluxes are available from state-of-the art atmospheric inversion models from the TransCom database at IPSL/LSCE (http://transcom.lsce.ipsl.fr; Peylin et al., 2012). Estimated fluxes from the following models are included in this analysis: C13_CCAM, C13_CCAM, Carbontracker_EU, Jena_S96_v3.2, JMA_2010, LSCE_an_v2.1, LSCE_var_v1.0, NICAM_MRI, RIGC_TDI64, TransCom-L3_mean. We also obtained regional specific inversion results for South Asia using the CARIBIC (Schuck et al., 2010) data in the upper troposphere over India and Pakistan, which is subsequently validated using the CONTRAIL (Machida et al., 2008) data of vertical profiles over Delhi and upper troposphere over Asia (Patra et al., 2011a). CONTRAIL observations are also used for inversion, with CARIBIC data for validation (Niwa et al., 2012). Measurements of atmospheric $\mathrm{CO}_{2}$ in the South Asian region are limited to Cabo de Rama, India, for the period of 1993-2002 (Bhattacharya et al., 2009). This site constrains the $\mathrm{CO}_{2}$ fluxes from India during winter to spring seasons only. Thus the use of aircraft measurements is indispensable for top-down flux estimates over the full seasonal cycle.

\subsection{Methane fluxes}

Top-down estimates: global distributions of $\mathrm{CH}_{4}$ emissions are prepared using site scale field measurements, inventories (in the case of fossil $\mathrm{CH}_{4}$ emissions and livestock emissions) and their extrapolation using remote sensing of wetland distribution and terrestrial ecosystem models (e.g. Mathews and Fung, 1987; Olivier and Berdowski, 2001; Ito and Inatomi, 2012). Components of these bottom-up estimations are scaled and used as an input to chemistry-transport models and compared with atmospheric mixing ratio measurements, or are used as prior flux estimates for inverse modeling of surface $\mathrm{CH}_{4}$ fluxes (Patra et al., 2011a; Bousquet at al., 2006 and references therein). Patra et al. (2011b) prepared 6 distinct $\mathrm{CH}_{4}$ budgets; 5 of those being anthropogenic sources (EDGAR, 2010; version 3.2, 4.0) in combination with natural sources due to wetlands (Ringeval et al., 2010; Ito and Inatomi, 2012), biomass burning (van der Werf et al., 2006), and those from Fung et al. (1991), and one being based on inversion of atmospheric concentrations (Bousquet et al., 2006).

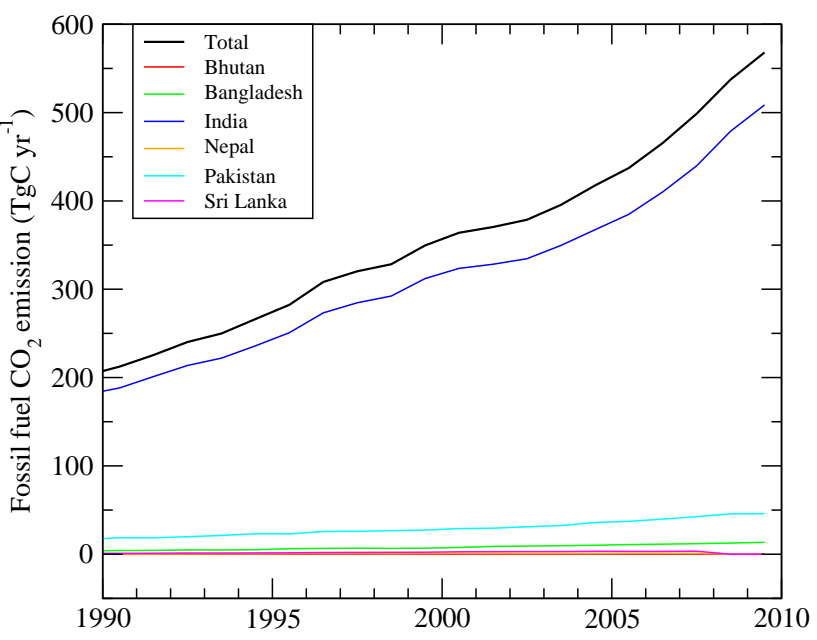

Fig. 2. Time series of $\mathrm{CO}_{2}$ emissions due to fossil fuel consumption and cement production from the South Asian region during the period of 1990-2009 (source: Boden et al., 2011).

Bottom-up estimates for India: methane fluxes for India were estimated using bottom-up inventory data which relied on SPOT Vegetation NDVI, Radarsat Scan SAR (SN2) and IRS AWiFS to map the different rice lands and generate the feed/fodder area for livestock consumption (Manjunath et al., 2011; Chhabra et al., 2009a).

Methane fluxes are given in the units of $\mathrm{TgC}-\mathrm{CH}_{4}$, by accounting for the mass of carbon atoms in $\mathrm{CH}_{4}\left(1 \mathrm{TgC}-\mathrm{CH}_{4}\right.$ is equivalent to $\frac{16}{12} \mathrm{Tg}$ of $\mathrm{CH}_{4}$ ).

\section{Results and discussion}

\subsection{Emissions from fossil fuels and cement production}

Figure 2 shows the fossil fuel and cement $\mathrm{CO}_{2}$ emissions trends over the South Asian region and member countries over the past two decades (see also Table 1). Growth rates are calculated as the slope of a fitted linear function, normalized by the average emissions for the period of interest. The average regional total emissions are estimated to be 278 and $444 \mathrm{TgCyr}^{-1}$ for the periods of 1990s and 2000s, respectively. The regional total emissions have steadily increased from $213 \mathrm{TgC} \mathrm{Cyr}^{-1}$ in 1990 to $573 \mathrm{TgC}^{-1}$ in 2009. About $90 \%$ of emissions from South Asia are due to fossil fuel consumptions in India at a normalized growth rate of $4.7 \% \mathrm{yr}^{-1}$ for the period of $1990-2009$. The decadal growth rates do not show large differences between the 1990s $\left(5.5 \% \mathrm{yr}^{-1}\right)$ and $2000 \mathrm{~s}\left(5.3 \% \mathrm{yr}^{-1}\right)$ for the whole region, while an increased rate of consumptions was observed after $2005\left(6.8 \% \mathrm{yr}^{-1}\right)$. This acceleration (Fig. 2) in fossil fuel consumption is largely due to the growth of the Indian economy, where the gross domestic product (GDP) doubled, from 34 trillion Indian Rupees in 2005 to 67 trillion Indian Rupees in 2010 (http://en.wikipedia.org/wiki/Economy_of_India). 
Table 1. Average fossil fuel $\mathrm{CO}_{2}$ emissions and annual growth rates (\%) for the decades of 1990s, 2000s, and the full RECCAP period (1990-2009).

\begin{tabular}{lrrrrrr}
\hline $\begin{array}{l}\text { Country/ } \\
\text { Region }\end{array}$ & $\begin{array}{r}\text { Average } \\
\text { Emissions } \\
\left(\mathrm{TgC} \mathrm{yr}^{-1}\right) \\
1990-2009\end{array}$ & $\begin{array}{r}\text { Growth } \\
\text { rate } \\
\left(\% \mathrm{yr}^{-1}\right)\end{array}$ & $\begin{array}{r}\text { Average } \\
\text { Emissions } \\
\left(\mathrm{TgC} \mathrm{yr}^{-1}\right)\end{array}$ & $\begin{array}{r}\text { Growth } \\
\text { Rate } \\
\left(\% \mathrm{yr}^{-1}\right) \\
1990-2009\end{array}$ & $\begin{array}{r}\text { Average } \\
\text { Emissions } \\
\left(\mathrm{TgC} \mathrm{yr}^{-1}\right)\end{array}$ & $\begin{array}{r}\text { Growth } \\
\text { Rate } \\
\left(\% \mathrm{yr}^{-1}\right)\end{array}$ \\
\hline Bangladesh & 8.207 & 6.2 & 5.638 & 6.0 & 10.775 & 6.1 \\
Bhutan & 0.113 & 7.8 & 0.072 & 11.4 & 0.154 & 8.5 \\
India & 319.81 & 4.7 & 247.44 & 5.6 & 392.18 & 5.3 \\
Nepal & 0.702 & 5.6 & 0.514 & 13.8 & 0.889 & 2.3 \\
Pakistan & 29.986 & 4.1 & 23.019 & 4.7 & 36.932 & 5.7 \\
Sri Lanka & 2.368 & 5.8 & 1.629 & 8.9 & 3.107 & 2.2 \\
South Asia & 361 & 5.7 & 278 & 8.4 & 444 & 5.0 \\
\hline
\end{tabular}

Table 2. Net emissions (+) and accumulations (-) of carbon $\left(\mathrm{TgC} \mathrm{Cr}^{-1}\right)$ attributed to different types of land use in South Asia.

\begin{tabular}{lrrrrrr}
\hline $\begin{array}{l}\text { Assessment } \\
\text { period }\end{array}$ & Crops & Plantation & $\begin{array}{r}\text { Industrial } \\
\text { harvest }\end{array}$ & $\begin{array}{r}\text { Fuelwood } \\
\text { harvest }\end{array}$ & $\begin{array}{r}\text { Shifting } \\
\text { cultivation }\end{array}$ & Total \\
\hline $1980-1989$ & 5 & -5 & 2 & -4 & 0 & -2 \\
$1990-1999$ & 6 & -11 & -1 & -5 & 0 & -11 \\
$2000-2010$ & 2 & -13 & 0 & -3 & 0 & -14 \\
\hline
\end{tabular}

\subsection{Emissions from land-use change (LUC)}

The annual net flux of carbon from land-use change in South Asia was a small sink $\left(-11 \mathrm{TgCyr}^{-1}\right.$ for the $1990 \mathrm{~s}$ and $-14 \mathrm{TgCyr}^{-1}$ for the period 2000-2009) (Table 2). The average sink over the 20-yr period 1990-2009 was $-12.5 \mathrm{TgC}^{-1}{ }^{-1}$. Three activities drove this net sink: establishment of tree plantations $\left(-13 \mathrm{TgC}^{-1}\right.$ in the most recent decade), wood harvest $\left(-3 \mathrm{TgC}^{-1}\right)$, and the expansion of croplands $\left(2 \mathrm{TgC}^{-1}\right)$. Wood harvest results in a net sink of carbon because both industrial wood and fuelwood harvesting have declined recently, while the forest ecosystem productivity remained constant (FRA, 2010).

Tree plantations (eucalyptus, acacia, rubber, teak, and pine) expanded by $0.2 \times 10^{6} \mathrm{hayr}^{-1}$ in the $1990-1999$ period and by $0.3 \times 10^{6}$ ha yr $^{-1}$ during 2000-2009 in the region (FRA, 2010). Uptake of carbon as a result of these new plantations, as well as those planted before 1990, averaged -11 and $-13{\mathrm{TgC} \mathrm{yr}^{-1}}^{-1}$ in the two decades, respectively.

Industrial and fuelwood harvest (including the emissions from wood products and the sink in regrowing forests) was

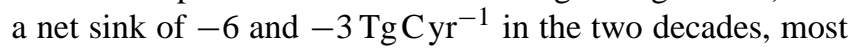
of this sink from fuelwood harvest. The net sink attributable to logging suggests that rates of wood harvest have declined in recent decades, while the recovery of forests harvested in previous years drives a net sink in forests.

The carbon sink in expanding plantations and growth of logged forests was offset only partially by the $\mathrm{C}$ source from the expansion of croplands, which is estimated to have released $6 \mathrm{TgC}^{-1}$ and $2 \mathrm{TgCyr}^{-1}$ during the 1990s and the first decade of 2000, respectively.
The net change in forest area in South Asia was zero for the decade 1990-1999 and averaged 200000 ha yr $^{-1}$ during 2000-2009 (FRA, 2010). Given the rates of plantation ex-

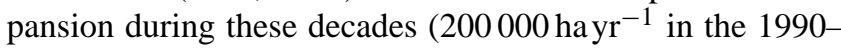
1999 period and by $300000 \mathrm{hayr}^{-1}$ during 2000-2009), native forests were lost at rates of $200000 \mathrm{hayr}^{-1}$ and 100000 ha yr$^{-1}$ in the two decades.

The large changes in forest area, both deforestation and afforestation, lead to gross emissions $\left(\sim 120 \mathrm{TgC}^{-1}\right)$ and a gross uptake $\left(\sim 135 \mathrm{TgC} \mathrm{yr}^{-1}\right)$ that are large relative to the net flux of $14{\mathrm{TgC} \mathrm{yr}^{-1}}^{-1}$. Thus, the uncertainty is greater than the net flux itself. The uncertainty is estimated to be $50 \mathrm{TgC}^{-1}$, a value is somewhat less than $50 \%$ of the gross fluxes.

The net flux for South Asia was determined to a large extent by land-use change (the expansion of tree plantations) in India, which accounts for $72 \%$ of the land area of South Asia, $85 \%$ of the forest area, and $>95 \%$ of the annual increase in plantations. Although 11 estimates of the net carbon flux due to land- use change for India published since 1980 have varied from a net source of $42.5 \mathrm{TgC} \mathrm{yr}^{-1}$ to

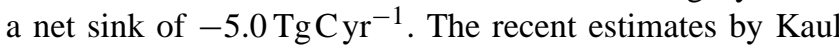
et al. (2009) for the late 1990s and up to 2009 suggest a declining source/increasing sink (Table 2), consistent with the findings reported here for all of South Asia.

Because India represents the largest contribution to landuse change in South Asia, and because there have been a number of analyses carried out for India, the discussion below focuses on India. A major theme of carbon budgets for India's forests has been the roles of tree plantations versus native forests. The 2009 Forest Survey of India (FSI) 
Table 3. Estimates of carbon emissions (+) and removals (-) from land-use change in India (from Kaul et al., 2009).

\begin{tabular}{lrrl}
\hline Assessment period & $\begin{array}{r}\text { Net C release } \\
\left(\mathrm{TgC} \mathrm{yr}^{-1}\right)\end{array}$ & $\begin{array}{r}\text { Deforestation } \\
\left(\mathrm{Mha} \mathrm{yr}^{-1}\right)\end{array}$ & Reference \\
\hline 1980 & -3.98 & - & Hall and Uhlig (1991) \\
1985 & 42.52 & 0.05 & Mitra (1992) \\
1986 & -5.00 & 0.49 & Ravindranath et al. (1997) \\
1987 & 38.21 & 1.50 & WRI (1990) \\
1990 & 0.40 & 0.06 & ALGAS (1998) \\
1991 & 5.73 & 0.34 & WRI (1994) \\
1994 & 12.8 & - & Haripriya (2003) \\
$1985-1996$ & 9.0 & - & Chhabra and Dadhwal (2004) \\
1994 & 3.86 & - & NATCOM (2004) \\
$1982-1992$ & 5.65 & 0.22 & Kaul et al. (2009) \\
$1992-2002$ & -1.09 & 0.07 & Kaul et al. (2009) \\
$1980-1989$ & -2 & - & This study \\
$1990-1999$ & -11 & - & This study \\
$2000-2009$ & -14 & - & This study \\
\hline
\end{tabular}

reported a $5 \%$ increase in India's forest area over the previous decade. This is a net change, however, masking the loss rate of native forests $(0.8 \%$ to $3.5 \%$ per year) and a large increase in plantations (eucalyptus, acacia, rubber, teak, or pine trees) of $\sim 5700 \mathrm{~km}^{2}$ to $\sim 18000 \mathrm{~km}^{2}$ per year (Puyravaud et al., 2010).

The same theme is evident in the earlier carbon budgets for India's forests. Ravindranath and Hall (1994) noted that, nationally, forest area declined slightly $(0.04 \%$, or 23750 ha annually) between 1982 and 1990. At the state level, however, adding up only those states that had lost forests (still an underestimate of gross deforestation), the loss of forest area was 497800 hayr $^{-1}$ between 1982 and 1986, and 266700 hayr $^{-1}$ between 1986 and 1988. These losses were obviously offset by "gross" increases in forest area in other states.

Similarly, Chhabra et al. (2002) found a net decrease of $\sim 0.6$ Mha in total forest cover for India, 1988-1994, while district-level changes indicated a gross increase of $1.07 \mathrm{Mha}$ and a gross decrease of $1.65 \mathrm{Mha}$. These changes in area translated into a decrease of $77.8 \mathrm{TgC}$ in districts losing forests and an increase of $81 \mathrm{Tg} \mathrm{C}$ in districts gaining forests (plantations) during the same period. It seems odd, though not impossible, that carbon accumulated during this period while forest area declined (Table 3). Clearly, the uncertainties are high.

This analysis did not include shifting cultivation in South Asia, but Lele and Joshi (2009) attributed much of the deforestation in northeast India to shifting cultivation. Houghton (2007) also omitted the conversion of forests to waste lands, while Kaul et al. (2009) attribute the largest fluxes of carbon to conversion of forests to croplands and wastelands. It seems unlikely that forests are deliberately converted to wastelands. Rather, wastelands probably result either from degradation of croplands (which are then replaced with new deforestation) or from over-harvesting of wood.

Fuelwood harvest, and its associated degradation of carbon stocks, and even deforestation, seems another primary driver of carbon emissions in South Asia. For example, Tahir et al. (2010) report that the use of fuelwood in brick kilns contributed to deforestation in Pakistan, where $14.7 \%$ of the forest cover was lost between 1990 and 2005.

In Nepal, Upadhyay et al. (2005) attribute the loss of carbon through land-use change to fuelwood consumption and soil erosion, and Awasthi et al. (2003) suggest that fuelwood harvest at high elevations of Himalayan India may not be sustainable. On the other hand, Unni et al. (2000) found that fuelwood harvest within a $100-\mathrm{km}$ radius of two cities showed both conversion of natural ecosystems to managed ones and the reverse, with no obvious net reduction in biomass. They inferred that the demand for fuelwood on forest and nonforest biomass was not great enough to degrade biomass.

The net sink estimated for South Asia in this study may have underestimated the emissions from forest degradation; logged forests were assumed to recover unless they were converted to another use. If wood removals exceed the rate of wood growth, carbon stocks will decline (forest degradation) and may ultimately be lost entirely (deforestation).

\subsection{Emissions from fires}

South Asia is not a large source of $\mathrm{CO}_{2}$ emission due to biomass burning as per the GFED3.1 (Global Fire Emission Database, version 3.1; van der Werf et al., 2006, 2010). Out of about $2,013 \pm 384 \mathrm{TgCyr}^{-1}$ of global total emissions due to open fires as detected by the various satellites sensors, only $47 \pm 30 \mathrm{TgCyr}^{-1}$ (2.3\% of the total) are emitted in the South Asian countries. The average and $1 \sigma$ standard deviations are calculated from the annual mean 
emissions in the period 1997-2009. The total emission is reduced to $44 \pm 13 \mathrm{TgCyr}^{-1}$ if the period of $2000-2009$ is considered. The total fire emissions can be attributed to agriculture waste burning $\left(14 \pm 4 \mathrm{TgCyr}^{-1}\right)$, deforestation fires $\left(21 \pm 11 \mathrm{TgCyr}^{-1}\right)$, forest fires $\left(2.6 \pm 1.5 \mathrm{TgC} \mathrm{yr}^{-1}\right)$, savanna burning $\left(4.8 \pm 1.9 \mathrm{TgCyr}^{-1}\right)$ and woodland fires $\left(1.8 \pm 1.0 \mathrm{Tg} \mathrm{Cyr}^{-1}\right)$ for the period of 2000-2009. The seasonal variation of $\mathrm{CO}_{2}$ emissions due to fires is discussed in Sect. 3.7.

Fire emissions due to agricultural activities will be largely recovered through the annual cropping cycles, and emissions from wildfires in natural ecosystems will be also largely recovered through regrowth over multiple decades (unless there is a fire regime change for which we have no evidence). For these reasons, carbon emissions from fires from the GFED product will not be used to estimate the regional carbon budget, given that fire emissions associated with deforestation are already included in the land-use change flux presented in this study. GFED fire fluxes are used to interpreted interannual variability.

\subsection{Riverine carbon flux}

The total carbon export from South Asian rivers was 42.9 $\mathrm{Tg} \mathrm{Cyr}^{-1}$, with COSCAT exports ranging from 0.01 to 33.4 $\mathrm{Tg} \mathrm{Cyr}^{-1}$ for the period of 1980-2000 (Table 4). Considering that about $611 \mathrm{TgC} \mathrm{yr}^{-1}$ is estimated to be released from global river systems (Cole et al., 2007; Battin et al., 2009), rivers in the South Asian region contribute about $7 \%$ of global riverine carbon export, which is more than twice the world average rate (the South Asian region has about $3 \%$ of the global land area). The largest riverine carbon export was observed from the Bengal Gulf COSCAT, which is dominated by the combined Ganges-Brahmaputra discharge. The riverine carbon exports from the other five remaining COSCAT basins were lower by up to two orders of magnitude, ranging from only 0.01 to $4.4 \mathrm{TgC} \mathrm{yr}^{-1}$ (Table 4).

Because large riverine carbon loads can be due to large basin area, we also provide the basin carbon yield (riverine carbon load per unit area, excluding PIC). Basin carbon yields varied by a few orders of magnitude, ranging from 0.04 to $18.4 \mathrm{~g} \mathrm{Cm}^{-2} \mathrm{yr}^{-1}$. The largest basin carbon yield was again from the Bengal Gulf COSCAT. However, Laccadive Basin COSCAT and West Deccan Coast COSCAT also released 9.5 and $8.2 \mathrm{gCm}^{-2} \mathrm{yr}^{-1}$, respectively. The global mean terrestrial carbon yield can be calculated by dividing the global riverine carbon export of $611 \mathrm{Tg} \mathrm{Cyr}^{-1}$ (Aufdenkampe et al., 2011; Battin et al., 2009) by the total land area of 149 million $\mathrm{km}^{2}$, providing a global mean yield of $4.1 \mathrm{~g} \mathrm{C} \mathrm{m}^{-2} \mathrm{yr}^{-1}$. Therefore, the three COSCAT regions in South Asia released more carbon per unit area than the global average. Considering that riverine carbon export is heavily dependent on discharge, this is not surprising since the three COSCAT regions have annual discharge values 40 to $120 \%$ larger than the global average discharge to the oceans of $340 \mathrm{~mm} \mathrm{yr}^{-1}$ (Mayorga et al., 2010).

The three COSCAT regions with the largest basin carbon yields (Bengal Gulf, Laccadive Basin, and West Deccan Coast) also corresponded to the area of highest NPP of South Asia (Kucharik et al., 2010), consistent with areas of cultivated crops and forested regions (Fig. 1). This suggests that terrestrial inputs of carbon, along with the riverine discharge, are the most significant factors in total riverine transport of carbon.

The relative contribution of DIC (Dissolved Inorganic Carbon), DOC (Dissolved Organic Carbon), and POC (Particulate Organic Carbon) to the total riverine carbon exports varied depending on the region. The Bengal Gulf COSCAT exported riverine DIC, DOC, and POC of 9.3, 7.0, and 17.1 $\mathrm{TgC}^{-1}$, respectively, demonstrating the strong POC contribution (Table 4). Riverine TSS (Total Suspended Sediment) loads and basin yields were also the largest from the Bengal Gulf COSCAT, indicating the strong correlation between POC and TSS.

The carbon emitted by soils to river headstreams can be degassed to the atmosphere as $\mathrm{CO}_{2}$ or deposited into sediment during the riverine transport from terrestrial ecosystem to oceanic ecosystem (Aufdenkampe et al., 2011; Cole et al., 2007). The estimated carbon release to the atmosphere from Indian (inner) estuaries (1.9 $\mathrm{Tg} \mathrm{Cyr}^{-1}$; Sarma et al., 2012) is relatively small compared to the total river flux of South Asia region. The monsoonal discharge through these estuaries have a short residence time of OC, which helps the OC matters to be transported relatively unprocessed to the open/deeper ocean. The average residence time during the monsoonal discharge period is less than a day, as observed over the period of 1986-2010, with longest residence time of 7 days for the years of low discharge rate (Acharyya et al., 2012). On an average the processing rate of OC in estuaries is estimated to be $30 \%$ in the Ganga-Brahmaputra river system in Bangladesh, and the remaining $70 \%$ are stored in the deep water of Bay of Bengal (Galy et al., 2007).

\subsection{Modeled long-term mean ecosystem fluxes from biosphere models}

Bottom-up estimates from all ten ecosystem models, forced by rising atmospheric $\mathrm{CO}_{2}$ concentration and changes in climate (S2 simulation), agree that terrestrial ecosystems of South Asia acted as a net carbon sink during 19802009. The average magnitude of the sink (NEP) estimated by the ten models is $-210 \pm 164 \mathrm{TgCyr}^{-1}$, ranging from $-80 \mathrm{TgC}^{-1}$ to $-651 \mathrm{TgCyr}^{-1}$. Rising atmospheric $\mathrm{CO}_{2}$ alone ( $\mathrm{S} 1$ simulation) accounts for $89-110 \%$ of the carbon sink estimated in the $\mathrm{CO}_{2}+$ Climate simulations (S2), suggesting a dominant role of the $\mathrm{CO}_{2}$ fertilization effect in driving the regional sink. The decadal average NEPs are $-193 \pm 136,-217 \pm 174$ and $-220 \pm 186 \mathrm{Tg} \mathrm{Cyr}^{-1}$, respectively, for the 1980s, 1990s and 2000s. The net primary 
Table 4. Riverine carbon exports from the COSCAT regions in South Asia as estimated by Global NEWS (TSS: Total Suspended Sediment; DIC: Dissolved Inorganic Carbon; DOC: Dissolved Organic Carbon; POC: Particulate Organic Carbon; TC: Total Carbon $(=\mathrm{DIC}+\mathrm{DOC}+\mathrm{POC})$.

\begin{tabular}{|c|c|c|c|c|c|c|c|c|c|}
\hline $\begin{array}{l}\text { COSCAT } \\
\text { number } \\
\text { Unit }\end{array}$ & $\begin{array}{l}\text { COSCAT } \\
\text { ID }\end{array}$ & $\begin{array}{r}\text { Basin } \\
\text { area } \\
10^{6} \mathrm{~km}^{2}\end{array}$ & $\begin{array}{l}\text { Discharge } \\
\mathrm{km}^{3} \mathrm{yr}^{-1}\end{array}$ & $\begin{array}{l}\text { Discharge } \\
\mathrm{mm} \mathrm{yr}^{-1}\end{array}$ & $\begin{array}{r}\text { TSS } \\
\text { load } \\
\text { Tg yr }^{-1}\end{array}$ & $\begin{array}{r}\text { DIC } \\
\text { load } \\
\text { Tg yr }^{-1}\end{array}$ & $\begin{array}{r}\text { DOC } \\
\text { load } \\
\text { Tg yr }^{-1}\end{array}$ & $\begin{array}{r}\text { POC } \\
\text { load } \\
\mathrm{Tg} \mathrm{yr}^{-1}\end{array}$ & $\begin{array}{r}\text { TC } \\
\text { Tg yr } \\
\end{array}$ \\
\hline 1336 & Bengal Gulf & 1815 & 1370 & 755 & 3411.7 & 9.3 & 7.0 & 17.07 & 33.4 \\
\hline 1337 & $\begin{array}{l}\text { East Deccan } \\
\text { Coast }\end{array}$ & 1118 & 270 & 241 & 153.7 & 1.8 & 1.2 & 1.33 & 4.4 \\
\hline 1338 & Laccadive Basin & 0.121 & 79 & 645 & 47.0 & 0.4 & 0.3 & 0.42 & 1.2 \\
\hline 1339 & $\begin{array}{l}\text { West Deccan } \\
\text { Coast }\end{array}$ & 0.337 & 160 & 475 & 136.4 & 1.2 & 0.7 & 0.85 & 2.8 \\
\hline 1340 & $\begin{array}{l}\text { Indus Delta } \\
\text { Coast }\end{array}$ & 1389 & 55 & 39 & 13.0 & 0.8 & 0.3 & 0.10 & 1.2 \\
\hline 1341 & Oman Gulf & 0.264 & 1 & 2 & 0.7 & 0.0 & 0.0 & 0.01 & 0.01 \\
\hline Sum & & 5046 & 1933 & 381 & 37617 & 13.6 & 9.5 & 19.8 & 42.9 \\
\hline
\end{tabular}

productivity (NPP) for the same decades are $2117 \pm 372$, $2160 \pm 372$ and $2213 \pm 358 \mathrm{TgC}^{-1}$, respectively.

Five of the eight models providing $\mathrm{CO}_{2}+$ Climate simulations (S2) show that climate change alone led to a carbon source of $0.1 \mathrm{TgCyr}^{-1}$ to $63 \mathrm{TgC} \mathrm{yr}^{-1}$ over the last three decades (the difference between simulation S2 and $\mathrm{S} 1$ ); the three other models (OCN, ORC and TRI) show that climate change enhanced the carbon sink by $-14,-6$ and $-4 \mathrm{TgCyr}^{-1}$. Such model discrepancies result in average net carbon flux driven by climate change as near neutral $\left(10 \pm 22 \mathrm{TgC} \mathrm{yr}^{-1}\right)$.

\subsection{Modeled long-term mean ecosystem fluxes from inversions}

Top-down estimates of land-atmosphere $\mathrm{CO}_{2}$ biospheric fluxes (i.e. without fossil fuel emissions, and inclusive of LUC flux and riverine export) are estimated by using atmospheric $\mathrm{CO}_{2}$ concentrations and chemistry-transport models. Results are available from 11 atmospheric inverse models participating in the TransCom intercomparison project with varying time periods between 1988-2008 (Peylin et al., 2012). The inversions were run without any observational data over the South Asian region for most part of the 2000s. Therefore, we place a very low confidence in the TransCom inversion results, and a medium confidence in the results of two additional regional inversions using aircraft measurements over the region. The estimated net land-atmosphere $\mathrm{CO}_{2}$ biospheric fluxes from the two regional inversions are -317 and $-88.3 \mathrm{TgCyr}^{-1}$ (Patra et al., 2011a; Niwa et al., 2012). The range of biospheric $\mathrm{CO}_{2}$ fluxes estimated by the 11 TransCom inversions is -158 to $507 \mathrm{TgCyr}^{-1}$, with a median value being a sink of $-35.4 \mathrm{TgCyr}^{-1}$ with a $1-\sigma$ standard deviation $182 \mathrm{TgCyr}^{-1}$. The median of the TransCom inversions is chosen for filtering the effect of outliers values. In summary, for this RECCAP carbon budget, we propose as a synthesis of the inversion approach the mean value of the two "best" inversions us- ing region-specific $\mathrm{CO}_{2}$ data and the median of TransCom models $\left(-147 \pm 150 \mathrm{TgC}^{-1}\right)$. For comparison, the NBP is calculated as $-104 \pm 150 \mathrm{Tg} \mathrm{Cyr}^{-1}$ (Top-down biospheric flux-Riverine export; further details of NBP calculation in Sect. 3.10.1).

\subsection{Seasonal variability of $\mathrm{CO}_{2}$ fluxes}

Figure 3 shows the comparisons of carbon fluxes as estimated by the terrestrial ecosystem models (NEP), atmospheric- $\mathrm{CO}_{2}$ inverse models (NBP) and fire emissions as estimated from satellite products and modeling. According to the ecosystem and inversion models, the peak carbon release is around April-May, while the peak of $\mathrm{CO}_{2}$ uptake is between July and October. The dynamics as seen by the TransCom (global) inversion models is quite unconstrained due to the lack of atmospheric measurements in the region. A recent study (Patra et al., 2011a) shows that the peak $\mathrm{CO}_{2}$ uptake rather occurs in the month of August when inversion is constrained by regional measurements from commercial aircrafts. The months of peak carbon uptake are consistent with regional climate seasonality, i.e., the observed maximum rainfall during June-August months. This predominantly tropical biosphere is likely to be limited by water availability as the average daytime temperatures over this region are always above $20^{\circ} \mathrm{C}$ and rainfall is very seasonal.

The peak-trough seasonal cycle amplitudes of NEP simulated by the ecosystem models are of similar magnitude $\left(\sim 300 \mathrm{Tg} \mathrm{Cyr}^{-1}\right)$ compared to those estimated by one of the inversions constrained by aircraft data (Patra et al., 2011a). The other regional inversion using atmospheric observations within the region estimated a seasonal cycle amplitude about $50 \%$ greater, mainly due to large $\mathrm{CO}_{2}$ release in the months of May and June (Niwa et al., 2012). A denser observational data network and field studies are required for narrowing the gaps between different source/sink estimations. 


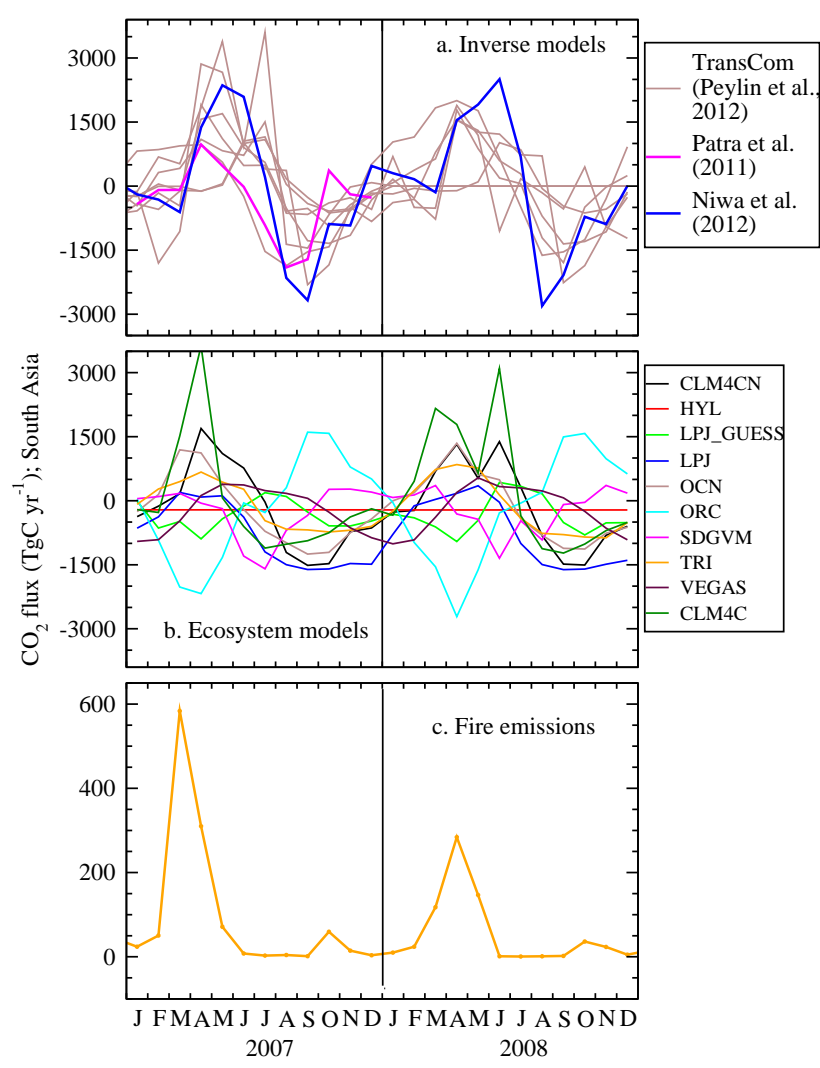

Fig. 3. Seasonal cycles of South Asian fluxes $\left(\mathrm{TgCyr}^{-1}\right)$ as simulated by atmospheric inversions (a, top panel), terrestrial ecosystem models (b, middle panel) and fire emissions modeling (c, bottom panel).

\subsection{Interannual variability of carbon fluxes}

Because aircraft $\mathrm{CO}_{2}$ observations over South Asia region are limited to only two years (2007 and 2008), we will exclude inverse model estimates from the discussions on interannual variability.

All ten terrestrial ecosystem models agree that there is no significant trend in the net carbon flux (positive values mean carbon source, negative values mean carbon sink) over South Asia from 1980 to 2009 (Fig. 4). The estimated net carbon flux (simulation scenario S2) over South Asia exhibits relatively large year-to-year change among the two simulation scenarios. The interannual variation of the $30-\mathrm{yr}$ net carbon flux estimated by the average of the ten models is $63 \mathrm{TgC}^{-1}$ measured by standard deviation, or $30 \%$ measured by coefficient of variation $(\mathrm{CV})$. In fact, the $\mathrm{CV}$ of the 30 -yr net carbon flux estimated by different models show a large range from $14 \%$ to $166 \%$, and only two models show a CV of larger than $100 \%$.

The model ensemble unanimously shows that interannual variations in simulated net carbon flux is driven by the interannual variability in gross primary productivity (GPP) rather than that in terrestrial heterotrophic respiration $\left(H_{\mathrm{R}}\right)$, sug-

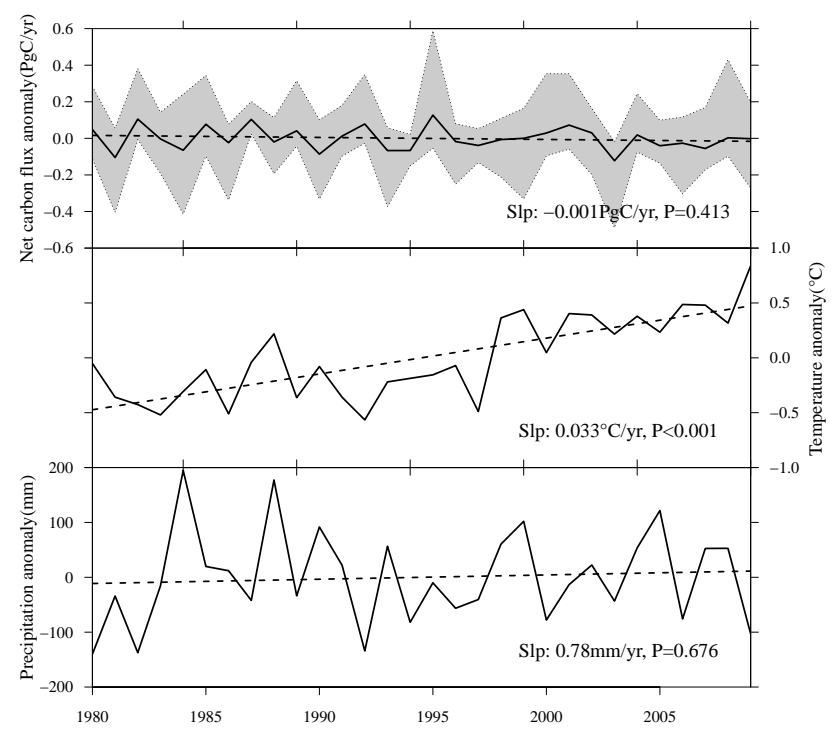

Fig. 4. Interannual variations in net carbon flux (top panel), annual temperature (middle panel) and annual precipitation (bottom panel) over South Asia from 1980 to 2009. Dashed lines show the least squared linear fit with statistics shown in text. Grey area in the top panel shows the range of net carbon flux anomalies estimated by the eleven ecosystem models.

gesting that variations in vegetation productivity play a key role in regulating variations of the net carbon flux. Similar results were also found in other regions such as Africa (Ciais et al., 2009).

To study the effect of climate change on net carbon flux variations, we performed correlation analyses between detrended anomalies of the modeled net carbon flux and detrended anomalies of climate (annual temperature and annual precipitation) over the last three decades (see Methods section). All models predict that carbon uptake decrease or reversed into net carbon source responding to increasing temperature, with two models (LPJ_GUESS and VEGAS) showing this positive correlation between temperature and net carbon flux statistically significant $(r>0.4, P<0.05)$. Regarding the response to precipitation change, eight of the ten models predict more carbon uptake in wetter years, particularly for LPJ; TRIFFID shows a statistically significant $(P<0.05)$ negative correlation between precipitation and net carbon flux. Thus, warm and dry years, such as 1988 and 2002 , tend to have positive net carbon flux anomalies (less carbon uptake or net carbon release). This further implies that the warming trend and the and non-significant trend in precipitation (Fig. 4) during the last three decades over South Asia might not benefit carbon uptake by terrestrial ecosystems, although models do not fully agree on the dominant climate driver of interannual variability in the net carbon flux. Six of the models (NCAR_CLM4CN, HyLand, LPJ, OCN, ORCHIDEE and TRIFFID) show interannual variability in net carbon flux closely associated with variability in 
precipitation rather than in temperature. The precipitation is also found to be the main driver of seasonal variation in South Asian $\mathrm{CO}_{2}$ flux (Patra et al., 2011a).

\subsection{Methane emissions}

\subsubsection{Top-down and bottom-up South Asian $\mathrm{CH}_{4}$ emissions}

The South Asian $\mathrm{CH}_{4}$ emissions are calculated from 6 scenarios prepared for the TransCom- $\mathrm{CH}_{4}$ experiment (Patra et al., 2011b). Five of the emission scenarios are constructed by combining inventories of various anthropogenic/natural emissions and wetland emission simulated by a terrestrial ecosystem model (bottom-up), and one is from atmospheric$\mathrm{CH}_{4}$ inversion (top-down). The estimated $\mathrm{CH}_{4}$ emissions are in the range of 33.2 to $43.7 \mathrm{Tg} \mathrm{C}-\mathrm{CH}_{4} \mathrm{yr}^{-1}$ for the period of 2000-2009, with an average value of $37.2 \pm 3.7$ ( $1 \sigma$ of 6 emission scenarios) $\mathrm{TgC}-\mathrm{CH}_{4} \mathrm{yr}^{-1}$.

\subsubsection{Bottom-up $\mathrm{CH}_{4}$ emissions from agriculture in India - implications for the South Asian budget}

Livestock production and rice crop cultivation are the two major sources of $\mathrm{CH}_{4}$ emissions from the agriculture sector. The reported emissions due to enteric fermentation and rice cultivation were $6.6 \mathrm{TgC}-\mathrm{CH}_{4} \mathrm{yr}^{-1}$ and $3.1 \mathrm{TgC}-\mathrm{CH}_{4} \mathrm{yr}^{-1}$, respectively, using emission factors appropriate for the region (NATCOM, 2004). India is a major rice-growing country with a very diverse rice growing environment: continuously or intermittently flooded, with or without drainage, irrigated or rain fed and drought prone. The average emission coefficient derived from all categories weighted for

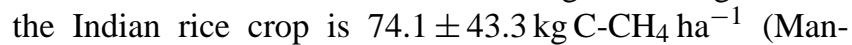
junath et al., 2011). The total mean emission (revised estimate) from the rice lands of India was estimated at $2.5 \mathrm{TgC}-\mathrm{CH}_{4} \mathrm{yr}^{-1}$. The wet season contributes about $2.3 \mathrm{TgC}-\mathrm{CH}_{4} \mathrm{yr}^{-1}$ amounting to $88 \%$ of the emissions. The emissions from drought-prone and flood-prone regions are $42 \%$ and $18 \%$ of the wet season emissions, respectively.

India has the world's largest total livestock population with 485 million in 2003, which accounts for $\sim 57 \%$ and $16 \%$ of the world's buffalo and cattle populations, respectively. Methane emissions from livestock have two components: emission from "enteric fermentation" and "manure management". Results showed that the total $\mathrm{CH}_{4}$ emission from Indian livestock, including enteric fermentation and manure management, was $11.8 \mathrm{Tg} \mathrm{CH}_{4}$ for the year 2003 . Enteric fermentation itself accounts for $8.0 \mathrm{TgC}-\mathrm{CH}_{4} \mathrm{yr}^{-1}$ $(\sim 91 \%)$. Dairy buffalo and indigenous dairy cattle together contribute $60 \%$ of the total $\mathrm{CH}_{4}$ emission. The three states with high live stock $\mathrm{CH}_{4}$ emission are Uttar Pradesh $(14.9 \%)$, Rajasthan $(9.1 \%)$ and Madhya Pradesh $(8.5 \%)$. The average $\mathrm{CH}_{4}$ flux from Indian livestock was estimated at $55.8 \mathrm{kgC}^{-} \mathrm{CH}_{4} \mathrm{ha}^{-1}$ feed/fodder area (Chhabra et al., 2009a).
The milching livestock constituting $21.3 \%$ of the total live-

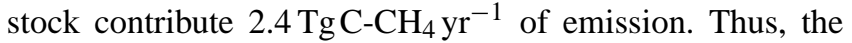
$\mathrm{CH}_{4}$ emission per $\mathrm{kg}$ milk produced amounts to $26.9 \mathrm{~g} \mathrm{C}$ $\mathrm{CH}_{4} \mathrm{~kg}^{-1}$ milk (Chhabra et al., 2009b).

These $\mathrm{CH}_{4}$ emission estimations of $8.8 \mathrm{TgC} \mathrm{yr}^{-1}$ from livestock are in good agreement with those of 8.8 (enteric fermentation + manure management) $\mathrm{TgC}^{-1} \mathrm{Cr}^{-1}$ in the Regional Emission inventory in Asia (REAS) for the year 2000 (Yamaji et al., 2003; Ohara et al., 2007), while emissions from rice cultivation of $2.5 \mathrm{TgC} \mathrm{yr}^{-1}$ is about half of $4.6 \mathrm{TgC}^{-1}$, estimated by Yan et al. (2009).

The REAS estimated total $\mathrm{CH}_{4}$ emissions due to anthropogenic sources (waste management and combustion, rice cultivation, livestock) from South Asia is $25 \mathrm{TgCyr}^{-1}$ for the year 2000, with 6.5, 11.3 and 7.2 $\mathrm{TgC}^{-1}$ are emitted due to rice cultivation, livestock and waste management. To match the range of the total flux from South Asia suggested by bottom-up inventories and atmospheric inversions (33.2$43.7 \mathrm{TgC} \mathrm{yr}^{-1}$ ), the remaining $\mathrm{CH}_{4}$ sources (mostly natural wetlands and biomass burning) for balancing total emissions from South Asia are in the range of $8-19 \mathrm{TgC}^{-1}$. The combination of bottom-up estimations of all $\mathrm{CH}_{4}$ sources types from all the member nations with top-down estimates can help close the methane budget in South Asia.

\subsection{The carbon budget}

\subsubsection{Mean annual $\mathrm{CO}_{2}$ budget}

Figure 5 and Table 5 show the estimates of regional total $\mathrm{CO}_{2}$-carbon emissions from different source types as discussed above. A fraction of the $\mathrm{CO}_{2}$ emissions from fossil fuel burning (444 $\mathrm{TgC}^{-1}$, averaged over 2000-2009) is probably taken up by the ecosystem within the region as suggested by the net biome productivity (NBP) estimated at $-191 \pm 193 \mathrm{Tg} \mathrm{Cyr}^{-1}$ by bottom-up methods, and at $-104 \pm 150 \mathrm{TgC} \mathrm{yr}^{-1}$ estimated by top-down methods. The bottom-up NBP is estimated as the sum of terrestrial ecosystem simulated net ecosystem production (NEP), uptake and emissions due to land-use change (LUC), and carbon export through the river system. The estimated $\mathrm{CO}_{2}$ release due to fires $\left(44 \mathrm{TgC} \mathrm{Cyr}^{-1}\right)$ is of similar magnitude than the flux transported out of the land to the coastal oceans by riverine discharge $\left(42.9 \mathrm{Tg} \mathrm{Cyr}^{-1}\right)$, but fire emissions are not included in the budget because are largely taken into account in the LUC component. Considering the net balance of these source types (including all biospheric and fossil fuel fluxes of $\mathrm{CO}_{2}$ ), the South Asian subcontinent is a net source of $\mathrm{CO}_{2}$, with a magnitude in the range of 340 (top-down) to 253 (bottom-up) $\mathrm{TgCyr}^{-1}$ in the period 2000-2009. We choose the mean value of $297 \pm 244 \mathrm{TgC} \mathrm{yr}^{-1}$ from the two estimates as our best estimate for the net land-atmosphere $\mathrm{CO}_{2}$ flux for the South Asian region. 


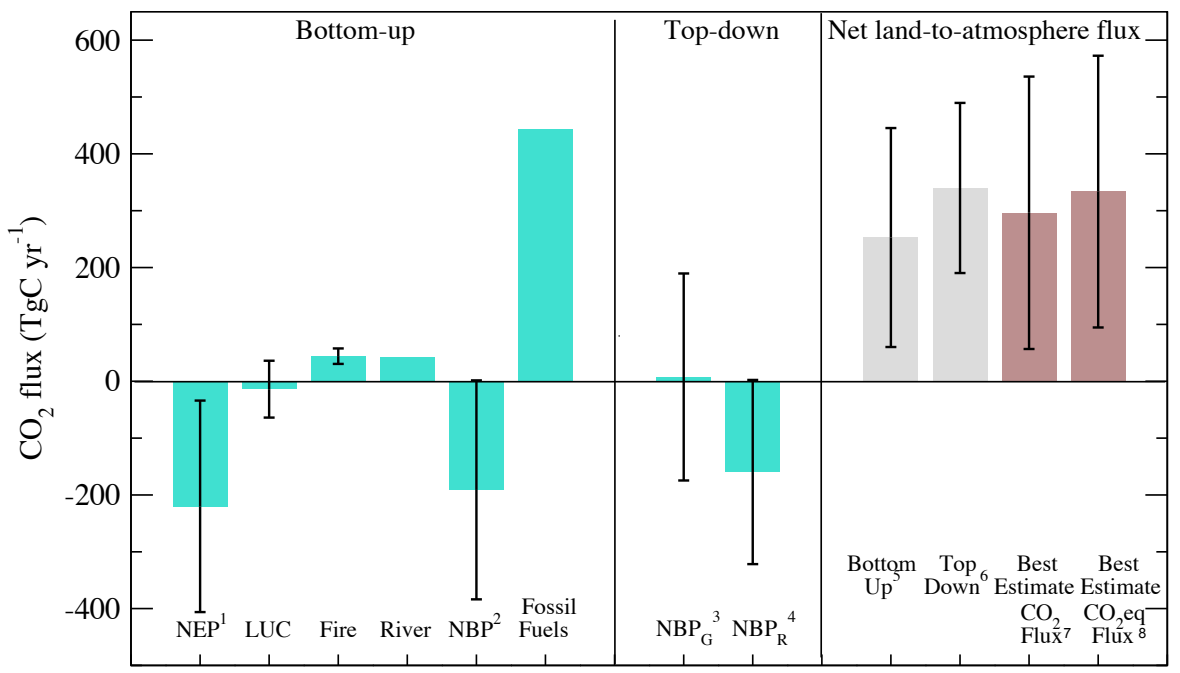

\footnotetext{
(1) Net Ecosystem Productivity (NEP) = NPP - heterotrophic respiration

(2) Net Biome Productivity = Sum of NEP, LUC, Fire, River (NBP = NEP - disturbances and lateral transport)

(3) Equivalent to NBP based on global $\mathrm{CO}_{2}$ atmospheric inversions $\left(\mathrm{NBP}_{\mathrm{G}}\right)$

(4) Equivalent to NBP based on region-specific $\mathrm{CO}_{2}$ atmospheric inversions $\left(\mathrm{NBP}_{\mathrm{R}}\right)$

(5) Bottom Up $=\mathrm{NBP}^{2}+$ Fossil Fuel emissions

(6) Top Down $=$ Weighted mean of $\mathrm{NBP}_{\mathrm{G}}{ }^{3}$ and $\mathrm{NBP}_{\mathrm{R}}{ }^{4}+$ Fossil Fuel emissions

(7) Best estimate $\mathrm{CO}_{2}$ flux (mean of bottom-up ${ }^{5}$ and top-down ${ }^{6}$ estimates)

(8) Best estimate $\mathrm{CO}_{2}$-equivalent $\left(\mathrm{CO}_{2}\right.$ eq) flux that includes $\mathrm{CO}_{2}$ and $\mathrm{CH}_{4}$ fluxes
}

Fig. 5. Decadal mean $\mathrm{CO}_{2}$ fluxes from various estimates and flux components. The period of estimations differ for source types (ref. Tables 5 and 6 for details).

Table 5. Decadal average $\mathrm{CO}_{2}$ fluxes from the South Asian region using bottom-up estimations, top-down estimations and terrestrial ecosystem models. The range of estimate is given as maximum and minimum, and $1-\sigma$ standard deviations as the estimated uncertainty or from interannual variability (IAV).

\begin{tabular}{|c|c|c|c|}
\hline Flux category & 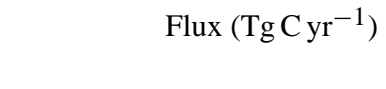 & $\begin{array}{l}\text { Assessment } \\
\text { period }\end{array}$ & Source \\
\hline Fossil fuel & +444 (range: +364 to +573$)$ & 2000-2009 & Boden et al. (2011) \\
\hline Land-use change & $-14 \pm 50$ & 2000-2009 & This study based on Houghton et al. (2007) \\
\hline Open fires & $+44.1 \pm 13.7(\mathrm{IAV})$ & 2000-2009 & GFEDv3.1 \\
\hline $\begin{array}{l}\text { Riverine discharge } \\
(\mathrm{DIC}+\mathrm{DOC}+\mathrm{POC})\end{array}$ & -42.9 & $1980-2000$ & $\begin{array}{l}\text { This study based on Global NEWS, } \\
\text { (Mayorga et al., 2010) }\end{array}$ \\
\hline $\begin{array}{l}\text { Atmospheric- } \mathrm{CO}_{2} \\
\text { inverse model }\end{array}$ & $\begin{array}{r}-35.4 \text { (model range: } \\
-158 \text { to }+507)\end{array}$ & 1997-2006 & TransCom (Peylin et al., 2012) \\
\hline Region-specific $\mathrm{CO}_{2}$ inversion & -317 to -88.3 & 2007-2008 & Patra et al. (2011a), Niwa et al. (2012) \\
\hline Ecosystem models (NEP) & $-220 \pm 186$ & 2000-2009 & Multiple models \\
\hline
\end{tabular}

\subsubsection{The mean annual carbon $\left(\mathrm{CO}_{2}+\mathrm{CH}_{4}\right)$ budget}

Table 6 shows the emission and sinks of $\mathrm{CO}_{2}$ and $\mathrm{CH}_{4}$ for the South Asian region. The best estimate of the total carbon or $\mathrm{CO}_{2}$-equivalent $\left(\mathrm{CO}_{2}\right.$-eq $\left.=\mathrm{CO}_{2}+\mathrm{CH}_{4}\right)$ flux is $334 \mathrm{TgCyr}^{-1}$, calculated with the average $\mathrm{CH}_{4}$ emissions of $37 \mathrm{TgC} \mathrm{yr}^{-1}$ and best estimate of $\mathrm{CO}_{2}$ emissions of $297 \mathrm{TgCyr}^{-1}$. For this $\mathrm{CO}_{2}$-eq flux, we assumed all $\mathrm{CH}_{4}$ is oxidized to $\mathrm{CO}_{2}$ in the atmosphere within about $10 \mathrm{yr}(\mathrm{Pa}-$ tra et al., 2011b). However, it is well known that $\mathrm{CH}_{4}$ exerts 23 times more radiative forcing (RF) than $\mathrm{CO}_{2}$ over a $100-\mathrm{yr}$ period (IPCC, 2001). For estimating the role of South Asia in global warming, the region contributes $\mathrm{RF}$-weighted $\mathrm{CO}_{2}$-eq emission of $1148(297+37 \times 23) \mathrm{TgCyr}^{-1}$. The net RFweight $\mathrm{CH}_{4}$ emission from the South Asian region is more than double of that released as $\mathrm{CO}_{2}$ from fossil fuel emissions. This result suggests that mitigation of $\mathrm{CH}_{4}$ emission should be given high priority for policy implementation. The effectiveness of $\mathrm{CH}_{4}$ emission mitigation is also greater due to shorter atmospheric lifetime compared to $\mathrm{CO}_{2}$. 
Table 6. Annual fluxes of $\mathrm{CO}_{2}$ and $\mathrm{CH}_{4}\left(\mathrm{TgCyr}^{-1}\right)$. The best-estimate net flux is computed using the mean of top-down and bottom-up estimates.

\begin{tabular}{lrrrr}
\hline Gas species & \multicolumn{2}{c}{ Average fluxes } & Best estimate & $\begin{array}{r}\text { RF-weighted } \mathrm{CO}_{2} \text {-eq } \\
(100 \text { yr horizon) }\end{array}$ \\
\cline { 2 - 4 } & Bottom-up & Top-down & & 297 \\
\hline $\mathrm{CO}_{2}$ & $-191 \pm 186$ & $-104 \pm 150$ & $\begin{array}{r}-147 \pm 239 \text { (NBP) } \\
+444 \text { (fossil fuel) }\end{array}$ \\
$\mathrm{CH}_{4}$ & $37.9 \pm 3.6$ & $33.2-43.7$ & 37 (total emission) & 851 \\
\hline Total & & & 334 & 1148 \\
\hline
\end{tabular}

\section{Future research directions}

The top-down and bottom-up estimations of carbon fluxes showed good agreement within their respective uncertainties, because we are able to account for the major flow of carbon in to and out of the South Asian region. However, there are clearly some missing flux components that require immediate attention. The fluxes estimated and not estimated in this work are schematically depicted in Fig. 6. Most notably the soil carbon pool and fluxes have not been incorporated in this analysis. The soil organic carbon (SOC) sequestration potential of the South Asian region is estimated to be in the range of 25 to $50 \mathrm{Tg} \mathrm{Cyr}^{-1}$ by restoring degraded soil and changing cropland management practices (Lal, 2004). The carbon fluxes associated with international trade (e.g. wood and food products) are likely to be minor contributor to the total budget of South Asia, as the region is not a major exporter/importer of these products (FRA, 2010). The region is a major importer of coal and gas for supporting the energy supply (UN, 2010). These flux components, along with several others identified in Fig. 6, will be addressed in the working group of South and Southeast Asian Greenhouse Gases Budget during a 3-yr project of the Asia-Pacific Network (2011-2014).

\section{Conclusions}

We have estimated all major natural and anthropogenic carbon $\left(\mathrm{CO}_{2}\right.$ and $\left.\mathrm{CH}_{4}\right)$ sources and sinks in the South Asian region using bottom-up and top-down methodologies.

Excluding fossil fuel emissions and by accounting for the riverine carbon export, we estimated a top-down $\mathrm{CO}_{2}$ sink for the 2000s (equal to the Net Biome Productivity) of $-104 \pm 150 \mathrm{TgC}^{-1}$ based on recent inverse model simulations using aircraft measurements and the median of multimodel estimates. The flux is in fairly good agreement with the bottom-up $\mathrm{CO}_{2}$ flux estimate of $-191 \pm 186 \mathrm{TgC}^{-1}$ based on the net balance of the following fluxes: net ecosystem productivity, land-use change, fire, and river export. These results show the existence of a globally modest biospheric sink, but a quite significant regionally and per area

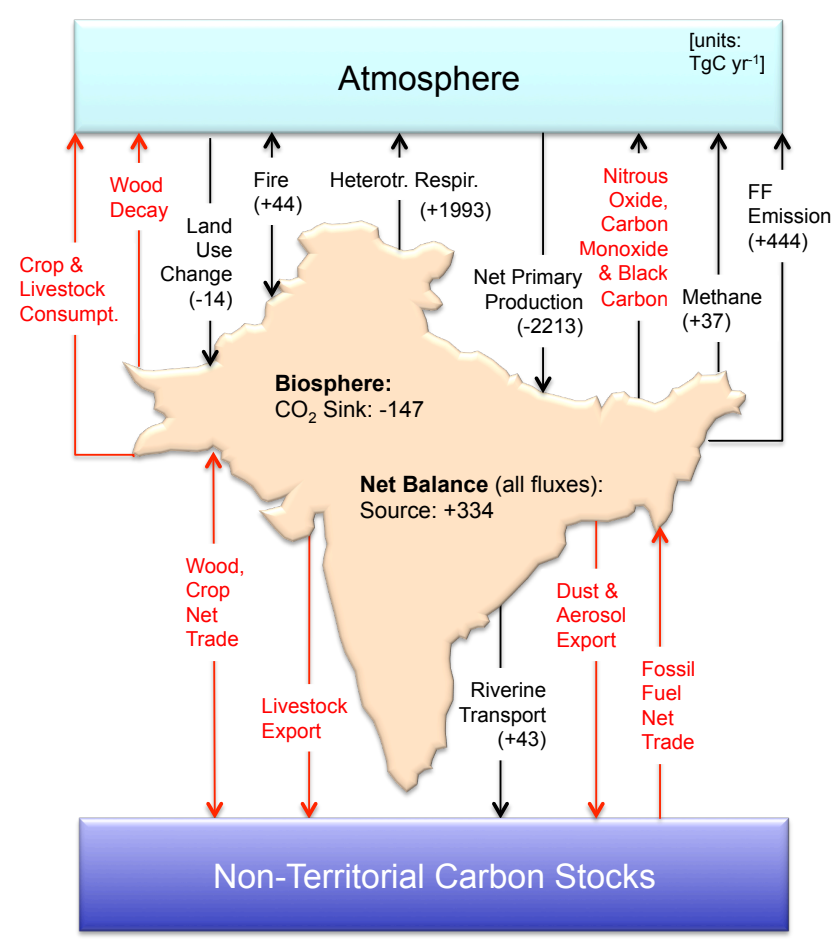

Fig. 6. Schematic diagram of major fluxes of $\mathrm{CO}_{2}, \mathrm{CH}_{4}$ nitrous oxide $\left(\mathrm{N}_{2} \mathrm{O}\right)$ and related species in the South Asia region. The flux components written in black ink are discussed in this work, and those marked in red ink requires attention for further strengthening of our knowledge in regional GHGs budget. Direction of net carbon flow has not been determined well for some of the fluxes, which are represented by lines with arrowheads on both sides.

sink driven by the net growth and expansion of vegetation. In a longer time frame, the South Asian sink is also benefiting from the $\mathrm{CO}_{2}$ fertilization effect on vegetation growth.

Including fossil fuel emissions, our best estimate of the net $\mathrm{CO}_{2}$ land-atmosphere flux is a source of $297 \pm 244 \mathrm{TgCyr}^{-1}$ from the average of top-down and bottom-up estimates, and a net $\mathrm{CO}_{2}$-equivalent, including both $\mathrm{CO}_{2}$ and $\mathrm{CH}_{4}$, land-atmosphere flux of $334 \mathrm{TgC} \mathrm{yr}^{-1}$ for the 2000s. We calculate that the RF-weighted total $\mathrm{CH}_{4}$ emission is $851 \mathrm{TgCyr}^{-1}$ from the South Asian region. In 
terms of $\mathrm{CO}_{2}$-equivalent flux, methane is largely dominating the budget, at a 100-yr horizon, because of its larger warming potential compared to $\mathrm{CO}_{2}$. This indicates that a mitigation policy for $\mathrm{CH}_{4}$ emission is preferred over fossil fuel $\mathrm{CO}_{2}$ emission control or carbon sequestration in forested land.

Further constraints in the carbon budget of South Asia to reduce current differences between the bottom-up and topdown estimates will require the expansion of atmospheric observations including key isotopes of greenhouse gases and the continuous development of inverse modeling systems that can use a diverse set of data streams including remote sensing data. In addition, terrestrial ecosystem models will need to properly represent the crops given the large role of agriculture in the region, better constrain the role of wetlands in the methane budget, and expand observations on riverine carbon transport and its ultimate fate in the coastal and open oceans.

Acknowledgements. This work is a contribution to the REgional Carbon Cycle Assessment and Processes (RECCAP), an activity of the Global Carbon Project. The work is partly supported by JSPS/MEXT (Japan) KAKENHI-A (grant\#22241008) and Asia Pacific Network (grant\#ARCP2011-11NMY-Patra/Canadell). Canadell is supported by the Australian Climate Change Science Program of CSIRO-BOM-DCCEE. The inverse model results of atmospheric $\mathrm{CO}_{2}$ and terrestrial ecosystem model results are provided under TransCom (http://transcom.lsce.ipsl.fr) and TRENDY (http://www-lscedods.cea.fr/invsat/RECCAP) projects, respectively, and we appreciate all the modelers' contribution by providing access to their databases.

Edited by: C. Sabine

\section{References}

Acharyya, T., Sarma, V. V. S. S., Sridevi, B., Venkataramana, V., Bharti, M. D., Naidu, S. A., Kumar, B. S. K., Prasad, V. R., Bandopadhaya, D., Reddy, N. P. C., and Kumar, M. D.: Reduced river discharge intensify phytoplankton bloom in Godavari estuary, India, Mar. Chem., 132-133, 15-22, 2012.

ALGAS (Asian Lest-Cost Greenhouse Gas Abettment Strategy): Report vol. 4, Asian Development Bank, Manila, 1998.

Aufdenkampe, A. K., Mayorga, E., Raymond, P. A., Melack, J. M., Doney, S. C., Alin, S. R., Aalto, R. E., and Yoo, K.: Riverine coupling of biogeochemical cycles between land, oceans, and atmosphere, Front. Ecol. Environ., 9, 53-60, 2011.

Awasthi, A., Uniyal, S. K., Rawat, G. S., and Rajvanshi, A.: Forest resource availability and its use by the migratory villages of Uttarkashi, Garhwal Himalaya (India), Forest Ecol. Manag., 174, 13-24, 2003.

Battin, T. J., Luyssaert, S., Kaplan, L. A., Aufdenkampe, A. K., Richter, A., and Tranvik, L. J.: The boundless carbon cycle, Nat. Geosci., 2, 598-600, 2009.

Bhattacharya, S. K., Borole, D. V., Francey, R. J., Allison, C. E., Steele, L. P., Krummel, P., Langenfelds, R., Masarie, K. A., Tiwari, Y. K., and Patra, P. K.: Trace gases and $\mathrm{CO}_{2}$ isotope records from Cabo de Rama, India, Curr. Sci., 97, 1336-1344, 2009.
Boden, T. A., Marland, G., and Andres, R. J.: Global, Regional, and National Fossil-Fuel $\mathrm{CO}_{2}$ Emissions (1751-2008) Carbon Dioxide Information Analysis Center, Environmental Sciences Division, Oak Ridge National Laboratory, Oak Ridge, TN 378316290, USA, 2011.

Bousquet, P., Ciais, P., Miller, J. B., Dlugokencky, E. J., Hauglustaine, D. A., Prigent, C., van der Werf, G. R., Peylin, P., Brunke, E.-G., Carouge, C., Langenfelds, R. L., Lathiére, J., Papa, F., Ramonet, M., Schmidt, M., Steele, L. P., Tyler, S. C., and White, J.: Contribution of anthropogenic and natural sources to atmospheric methane variability, Nature, 443, 439-443, 2006.

Bouwman, A. F., Boumans, L. J. M., and Batjes, N. H.: Modeling global annual $\mathrm{N}_{2} \mathrm{O}$ and $\mathrm{NO}$ emissions from fertilized fields, Global Biogeochem. Cy., 16, 1080, doi:10.1029/2001GB001812, 2002.

Canadell J. G., Ciais, P., Gurney, K., Le Quéré, C., Piao, S., Raupach M. R., and Sabine, C. L.: An international effort to quantify regional carbon fluxes, EOS, 92, 81-82, 2011.

Chhabra, A. and Dadhwal, V. K.: Assessment of pools and fluxes of carbon in Indian forests, Climatic Change, 64, 341-360, 2004.

Chhabra, A., Palria, S., and Dadhwal, V. K.: Spatial distribution of phytomass carbon in Indian forests, Global Change Biol., 8, 1230-1239, 2002.

Chhabra, A., Manjunath, K. R., Panigrahy, S., and Parihar, J. S.: Spatial pattern of methane emissions from Indian livestock, Current Sci., 96, 683-689, 2009a.

Chhabra, A., Manjunath, K. R., and Panigrahy, S.: Assessing the role of Indian livestock in climate change, in: The International Archives of the Photogrammetry, Remote Sensing and Spatial Information Sciences, XXXVIII Part 8/W3, ISPRS WG VIII/6 - Agriculture, Ecosystem and Bio-diversity-Space Applications Centre (ISRO), Ahmedabad, India Indian Society of Remote Sensing, Ahmedabad Chapter, http://www.isprs.org/ proceedings/XXXVIII/8-W3/, 359-365, 2009b.

Ciais, P., Piao, S.-L., Cadule, P., Friedlingstein, P., and Chédin, A.: Variability and recent trends in the African terrestrial carbon balance, Biogeosciences, 6, 1935-1948, doi:10.5194/bg-6-19352009, 2009.

Cicerone, R. J. and Shetter, J. D.: Sources of atmospheric methane: measurements in rice paddies and a discussion, J. Geophys. Res., 86, 7203-7209, 1981.

Cole, J. J., Prairie, Y. T. Caraco, N. F., McDowell, W. H., Tranvik, L. G., Striegl, R. G., Duarte, C. M., Kortelainen, P., Downing, J. A., Middelburg, J. J., and Melack, J.: Plumbing the global carbon cycle: integrating inland waters into the terrestrial carbon budget, Ecosystems, 10, 172-185, 2007.

DeFries, R. S. and Townshend, J. R. G.: NDVI-derived land cover classification at global scales, Int. J. Remote Sens., 15, 35673586, 1994.

Emissions Database for Global Atmospheric Research (EDGAR), European Commission, Joint Research Centre (JRC)/Netherlands Environmental Assessment Agency (PBL), release version 4.1, available at: http://edgar.jrc.ec.europa.eu, last access: 30 November 2010, 2010.

FRA: Global Forest Resource Assessment, Food and Agriculture Organization of the United Nations, Rome, 2010.

Fung, I., John, J., Lerner, J., Matthews, E., Prather, M., Steele, L. P., and Fraser, P. J.: Three-dimensional model synthesis of the global methane cycle, J. Geophys. Res., 96, 13033-13065, 1991. 
Galy, V., France-Lanord, C., Beyssac, O., Faure, P., Kudrass, H., and Palhol, F.: Efficient organic carbon burial in the Bengal fan sustained by the Himalayan erosional system, Nature, 450, 407410, 2007.

Goldewijk, K. K.: Estimating global land use change over the past 300 years: the HYDE database, Global Biogeochem. Cy., 15, 417-433, 2001.

Hall, C. A. S. and Uhlig, J.: Refining estimates of carbon released from tropical land-use change, Can. J. Forest Res., 21, 118-131, 1991.

Haripriya, G. S.: Carbon budget of the Indian forest ecosystem, Climatic Change, 56, 291-319, 2003.

Hartmann, J., Jansen, N., Dürr, H. H., Kempe, S., and Köhler, P.: Global $\mathrm{CO}_{2}$ consumption by chemical weathering: what is the contribution of highly active weathering regions?, Global Planet. Change, 69, 185-194, 2009.

Houghton, R. A.: Revised estimates of the annual net flux of carbon to the atmosphere from changes in land use and land management 1850-2000, Tellus B, 55, 378-390, 2003.

Houghton, R. A.: Balancing the global carbon budget, Annu. Rev. Earth Pl. Sc., 35, 313-347, 2007.

IPCC, Climate Change 2001: The Scientific Basis, Contribution of Working Group I to the Third Assessment Report of the Intergovernmental Panel on Climate Change, edited by: Houghton, J. T., Ding, Y., Griggs, D. J., Noguer, M., van der Linden, P. J., Da, X., Maskell, K., and Johnson, C. A., Cambridge Univ. Press, Cambridge, UK, 881 pp., 2001.

Ito, A. and Inatomi, M.: Use of a process-based model for assessing the methane budgets of global terrestrial ecosystems and evaluation of uncertainty, Biogeosciences, 9, 759-773, doi:10.5194/bg9-759-2012, 2012.

Kaul, M., Dadhwal, V. K., and Mohren, G. M. J.: Land use change and net $\mathrm{C}$ flux in Indian forests, Forest Ecol. Manag., 258, 100108, 2009.

Keeling, C. D., Piper, S. C., Bacastow, R. B., Wahlen, M., Whorf, T. P., Heimann, M., and Meijer, H. A.: Exchanges of atmospheric $\mathrm{CO}_{2}$ and ${ }^{13} \mathrm{CO}_{2}$ with the terrestrial biosphere and oceans from 1978 to 2000, I. Global aspects, SIO Reference Series, No. 01-06, Scripps Institution of Oceanography, San Diego, 88 pp., 2001.

Kucharik, C. J., Foley, J. A., Delire, C., Fisher, V. A., Coe, M. T., Lenters, J. D., Young-Molling, C., Ramankutty, N., Norman, J. M., and Gower, S. T.: Testing the performance of a dynamic global ecosystem model: water balance, carbon balance, and vegetation structure, Global Biogeochem. Cy., 14, 795-825, 2010

Lal, R.: The potential of carbon sequstration in soils of South Asia, in: Conserving Soil and Water for Society: Sharing Solutions, 13th International Soil Conservation Organisation Conference, Brisbane, paper no. 134, 1-6, July 2004.

Lele, N. and Joshi, P. K.: Analyzing deforestation rates, spatial forest cover changes and identifying critical areas of forest cover changes in North-East India during 1972-1999, Environ. Monit. Assess., 156, 159-170, 2009.

Machida, T., Matsueda, H., Sawa, Y., Nakagawa, Y., Hirotani, K., Kondo, N., Goto, K., Nakazawa, T., Ishikawa, K., and Ogawa, T.: Worldwide measurements of atmospheric $\mathrm{CO}_{2}$ and other trace gas species using commercial airlines, J. Atmos. Ocean. Tech., 25, 1744-1754, 2008.
Manjunath, K. R., Panigrahy, S., Adhya, T. K., Beri, V., Rao, K. V., and Parihar, J. S.: Methane emission pattern of Indian riceecosystems, J. Ind. Soc. Remote Sens., 39, 307-313, 2011.

Marland, G. and Rotty, R. M.: Carbon dioxide emissions from fossil fuels: a procedure for estimation and results for 1950-82, Tellus B, 36, 232-261, 1984.

Matthews, E. and Fung, I.: Methane emissions from natural wetlands: global distribution, area, and ecology of sources, Global Biogeochem. Cy., 1, 61-86, doi:10.1029/GB001i001p00061, 1987.

Mayorga, E., Seitzinger, S. P., Harrison, J. A., Dumon, E., Beusen, A. H. W., Bouwman, A. F., Fekete, B. M., Kroeze, C., and van Drecht, G.: Global nutrient export from WaterSheds 2 (NEWS 2): model development and implementation, Environ. Modell. Softw., 25, 837-853, 2010.

Meybeck, M., Durr, H. H., and Vorosmarty, C. J.: Global coastal segmentation and its river catchment contributors: a new look at land-ocean linkage, Global Biogeochem. Cy., 20, GB1S90, doi:10.1029/2005GB002540, 2006.

Mitra, A. P.: Greenhouse Gas Emissions in India - a Preliminary Report, No. 4, Council of Scientific and Industrial Research \& Ministry of Environment and Forests, New Delhi, 1992.

NATCOM: India's Initial National Communication to the United Nations Framework Convention on Climate Change, Ministry of Environment and Forest (MoEF), Govt. of India, New Delhi, 292 pp., 2004

Niwa, Y., Machida, T., Sawa, Y., Matsueda H., Schuck T. J., Brenninkmeijer C. A. M., Imasu R., and Satoh M.: Imposing strong constraints on tropical terrestrial $\mathrm{CO}_{2}$ fluxes using passenger aircraft based measurements, J. Geophys. Res., 117, D11303, doi:10.1029/2012JD017474, 2012.

Ohara, T., Akimoto, H., Kurokawa, J., Horii, N., Yamaji, K., Yan, X., and Hayasaka, T.: An Asian emission inventory of anthropogenic emission sources for the period 1980-2020, Atmos. Chem. Phys., 7, 4419-4444, doi:10.5194/acp-7-4419-2007, 2007.

Olivier, J. G. J. and Berdowski, J. J. M.: Global emissions sources and sinks, in: The Climate System, edited by: Berdowski, J., Guicherit, R., and Heij, B. J., ISBN 9058092550, A. A. Balkema Publishers/Swets \& Zeitlinger Pub., Lisse, The Netherlands, 33 78, 2001.

Patra, P. K., Takigawa, M., Ishijima, K., Choi, B.-C., Cunnold, D., Dlugokencky, E. J., Fraser, P., Gomez-Pelaez, A. J., Goo, T.Y., Kim, J.-S., Krummel, P., Langenfelds, R., Meinhardt, F., Mukai, H., O’Doherty, S., Prinn, R. G., Simmonds, P., Steele, P., Tohjima, Y., Tsuboi, K., Uhse, K., Weiss, R., Worthy, D., and Nakazawa, T.: Growth rate, seasonal, synoptic, diurnal variations and budget of methane in lower atmosphere, J. Meteorol. Soc. Jpn., 87, 635-663, 2009.

Patra, P. K., Niwa, Y., Schuck, T. J., Brenninkmeijer, C. A. M., Machida, T., Matsueda, H., and Sawa, Y.: Carbon balance of South Asia constrained by passenger aircraft $\mathrm{CO}_{2}$ measurements, Atmos. Chem. Phys., 11, 4163-4175, doi:10.5194/acp11-4163-2011, 2011a.

Patra, P. K., Houweling, S., Krol, M., Bousquet, P., Belikov, D., Bergmann, D., Bian, H., Cameron-Smith, P., Chipperfield, M. P., Corbin, K., Fortems-Cheiney, A., Fraser, A., Gloor, E., Hess, P., Ito, A., Kawa, S. R., Law, R. M., Loh, Z., Maksyutov, S., Meng, L., Palmer, P. I., Prinn, R. G., Rigby, M., Saito, R., 
and Wilson, C.: TransCom model simulations of $\mathrm{CH}_{4}$ and related species: linking transport, surface flux and chemical loss with $\mathrm{CH}_{4}$ variability in the troposphere and lower stratosphere, Atmos. Chem. Phys., 11, 12813-12837, doi:10.5194/acp-1112813-2011, 2011b.

Patra, P. K., Ito, A., and Yan, X.-Y.: Climate change and agriculture in Asia: a case study for methane emission due to rice cultivation, in: Impact of Climate Change in Soils and Rainfed Agriculture of Tropical Ecosystem, Chap. 13, edited by: Bhattacharya, T., Pal, D. K., Sarkar, D., and Wani, S. P., Studium Press LLC, New Delhi, 328 pp., 2012a

Patra, P. K., Canadell, J. G., and Lal, S.: The rapidly changing greenhouse gases (GHG) budget of Asia, EOS, 93, 237, doi:10.1029/2012EO250006, 2012b.

Peylin, P., Law, R. M., Gurney, K. R., Chevallier, F., Jacobson4, A. R., Maki, T., Niwa, Y., Patra, P. K., Peters, W., Rayner, P. J., Rödenbeck, C., and Zhang, X.: Global Atmospheric Carbon Budget: results from an ensemble of atmospheric $\mathrm{CO}_{2}$ inversions, Biogeosciences, in preparation, 2013.

Piao, S., Sitch, S., Ciais, P., Friedlingstein, P., Peylin, P., Wang, X., Ahlström, A., Anav, A., Canadell, J. G., Huntingford, C., Jung, M., Levis, S., Levy, P. E., Lomas, M. R., Lu, M., Luo, Y., Myneni, R. B., Poulter, B., Wang, T., Viovy, N., Zaehle, S., and Zeng, N.: Evaluation of terrestrial carbon cycle models for their sensitivity to climate variability and the observed rise in atmospheric $\mathrm{CO}_{2}$ abundance, Global Change Biol., in review, 2012.

Puyravaud, J.-P., Davidar, P., and Laurance, W. F.: Cryptic loss of India's native forests, Science, 329, 32, doi:10.1126/science.329.5987.32-b, 2010.

Ravindranath, N. H. and Hall, D. O.: Indian forest conservation and tropical deforestation, Ambio, 23, 521-523, 1994.

Ravindranath, N. H., Somashekhar, B. S., and Gadgil, M.: Carbon flow in Indian Forests, Climatic Change, 35, 297-320, 1997.

Ringeval, B., de Noblet-Ducoudré, N., Ciais, P., Bousquet, P., Prigent, C., Papa, F., and Rossow, W. B.: An attempt to quantify the impact of changes in wetland extent on methane emissions on the seasonal and interannual time scales, Global Biogeochem. Cy., 24, GB2003, doi:10.1029/2008GB003354, 2010.

Rotty, R. M.: First estimates of global flaring of natural gas, Atmos. Environ., 8, 681-86, 1974.

Sarma, V. V. S. S., Viswanadham, R., Rao, G. D., Prasad, V. R., Kumar, B. S. K., Naidu, S. A., Kumar, N. A., Rao, D. B., Sridevi, T., Krishna, M. S., Reddy, N. P. C., Sadhuram, Y., and Murty, T. V. R.: Carbon dioxide emissions from Indian monsoonal estuaries, Geophys. Res. Lett., 39, L03602, doi:10.1029/2011GL050709, 2012.

Schuck, T. J., Brenninkmeijer, C. A. M., Baker, A. K., Slemr, F., von Velthoven, P. F. J., and Zahn, A.: Greenhouse gas relationships in the Indian summer monsoon plume measured by the CARIBIC passenger aircraft, Atmos. Chem. Phys., 10, 39653984, doi:10.5194/acp-10-3965-2010, 2010.

Sitch, S., Friedlingstein, P., Gruber, N., Steve, J. S., MurrayTortarolo, G., Ahlström, A., Doney, S. C., Graven, H., Heinze, C., Huntingford, C., Levis, S., Levy, P. E., Lomas, M., Poulter, B., Viovy, N., Zaehle, S., Zeng, N., Arneth, A., Bonan, G., Bopp, L., Canadell, J. G., Chevallier, F., Ciais, P., Ellis, R., Gloor, M., Peylin, P., Piao, P., Le Quéré, C., Smith, B., Zhu, Z., Myneni: Trends and drivers of regional sources and sinks of carbon dioxide over the past two decades, Biogeosciences, submitted, 2012.
Tahir, S. N. A., Rafique, M., and Alaamer, A. S.: Biomass fuel burning and its implications: deforestation and greenhouse gases emissions in Pakistan, Environ. Pollut., 158, 2490-2495, 2010.

United Nations (UN): 2008 Energy Statistics Yearbook, United Nations Department for Economic and Social Information and Policy Analysis, Statistics Division, New York, 2010.

Unni, N. V. M., Naidu, K. S. M., and Kumar, K. S.: Significance of landcover transformations and the fuelwood supply potentials of the biomass in the catchment of an Indian metropolis, Int. J. Remote Sens., 21, 3269-3280, 2000.

Upadhyay, T. P., Sankhayan, P. L., and Solberg, B.: A review of carbon sequestration dynamics in the Himalayan region as a function of land-use change and forest/soil degradation with special reference to Nepal, Agr. Ecosyst. Environ., 105, 449-465, 2005.

US Department of Energy: International Energy Annual 1994, DOE/EIA-0219(91), Energy Information Administration, Office of Energy Markets and End Use, Washington, DC, 1994.

US Geological Survey: 2008 Minerals Yearbook - Cement, edited by: van Oss, H. G., US Department of the Interior, US Geological Survey, Reston, Virginia, 2010.

van der Werf, G. R., Randerson, J. T., Giglio, L., Collatz, G. J., Kasibhatla, P. S., and Arellano Jr., A. F.: Interannual variability in global biomass burning emissions from 1997 to 2004, Atmos. Chem. Phys., 6, 3423-3441, doi:10.5194/acp-6-3423-2006, 2006.

van der Werf, G. R., Randerson, J. T., Giglio, L., Collatz, G. J., Mu, M., Kasibhatla, P. S., Morton, D. C., DeFries, R. S., Jin, Y., and van Leeuwen, T. T.: Global fire emissions and the contribution of deforestation, savanna, forest, agricultural, and peat fires (1997-2009), Atmos. Chem. Phys., 10, 11707-11735, doi:10.5194/acp-10-11707-2010, 2010.

World Resources Institute (WRI), in collaboration with the United Nations Environment Programme and the United Nations Development Programme: World Resources 1990-91, A Guide to the Global Environment, Oxford University Press, Oxford, 1990.

World Resources Institute (WRI), in collaboration with the United Nations Environment Programme and the United Nations Development Programme: World Resources 1994-95, People and the Environment, Oxford University Press, Oxford, 420 pp., 1994.

Yamaji, K., Ohara, T., and Akimoto, H.: A country-specific, highresolution emission inventory for methane from livestock in Asia in 2000, Atmos. Environ., 37, 4393-4406, 2003.

Yan, X., Akiyama, H., Yagi, K. and Akimoto, H.: Global estimations of the inventory and mitigation potential of methane emissions from rice cultivation conducted using the 2006 Intergovernmental Panel on Climate Change Guidelines, Global Biogeochem. Cy., 23, GB2002, doi:10.1029/2008GB003299, 2009. 